\title{
THE IMPACT OF COVID-19 ON TOURISM SUSTAINABILITY: EVIDENCE FROM PORTUGAL
}

\author{
Fernando ALMEIDA ${ }^{1}$ \\ Faculty of Engineering, University of Porto $\mathcal{E}$ INESC TEC, Porto, Portugal \\ ORCID: 0000-0002-6758-4843 \\ Oscar SILVA \\ Higher Polytechnic Institute of Gaya, ISPGaya, V. N. Gaia, Portugal \\ ORCID: 0000-0002-0109-1050
}

\begin{abstract}
Portugal is a country in which the tourism sector assumes great importance, contributing around $15 \%$ of the national GDP and with more than 1 million jobs. In this sense, COVID-19 is expected to have a dramatic impact on the Portuguese economy aggravated by the existence of a reduced internal market with low purchasing power and in which there is a high dependence on the external market. This perspective study explores the challenges and opportunities that Portuguese companies in the field of tourism are facing due to the emergence of this pandemic. The challenges faced by companies are both short-term and long-term. In the short term, it is essential to ensure sufficient liquidity to reopen activities and in the long term, it is necessary to be prepared and reactive to disruptive movements that may arise in tourist demand. However, it is also important to recognize that some opportunities can be exploited, such as the quality of the health response, the exploitation of a less mass tourism supply based on the components of social and environmental sustainability, the increase of tourism among the elderly population from countries with greater purchasing power and the acceleration of the digitalization of tourism operations.
\end{abstract}

Article History

Received 29 July 2020

Revised 23 August 2020

Accepted 26 August 2020

Keywords

COVID-19

Sustainability

Challenges

Opportunities

Disruption

\footnotetext{
${ }^{1}$ Address correspondence to Fernando ALMEIDA, Faculty of Engineering, University of Porto \& INESC TEC, Porto, PORTUGAL.E-mail: almd@fe.up.pt
} 


\section{INTRODUCTION}

Tourism has been the engine of economic growth in Portugal in recent years. Starting from insignificant values at the end of the last century, tourism is already nowadays an important part of the national product and contributes significantly to the balance of trade, to the emergence of new infrastructures and the creation of employment. Currently, there is a consensus that tourism is a key strategic axis for the sustained development of the territory. In 2018, tourism in Portugal provided 1.047 million jobs, which is equivalent to $21.8 \%$ of total employment (PRESSTUR, 2019). Furthermore, it represents about $14.6 \%$ of the national GDP (TravelBI, 2019). According to the World Travel \& Tourism Council (WTCC) it is the 4th country with the highest rate of wealth generation by tourism (WEF, 2018).

The increase of tourism activity in Portugal in recent years was due, among other factors, to the capacity of initiative of entrepreneurs and the natural conditions offered by the territory (Moreira, 2018). The mild climate, the sunlight, and the proximity to the sea are factors widely highlighted and associated with natural conditions. In addition to the innate capacity of the Portuguese to welcome foreigners, there is also the entrepreneurial capacity of our companies, which have strengthened the offer of accommodation and multiplied the tourist entertainment. There has been international recognition of Portugal's attractiveness as a tourist destination, notably the World Travel Awards 2019 for the third consecutive year, the 11th edition of the Marketeer Awards, or the World Golf Awards 2018 as recognition as the best world and European golf destination. In Portugal, there are three regions where tourism has experienced significant development: Lisbon, Algarve and Madeira.

The effects of the pandemic caused by COVID-19 are having impact on the development of tourism activities worldwide (Gössling et al., 2020). Although many travel and tourism companies are used to including a risk management and assessment model in their business planning, like it is stated in Ural (2015) and Ritchie and Jiang (2019), the nature of this pandemic has put these models under strong pressure as their impacts manifest themselves on a global scale. Measures to contain and restrict the mobility of citizens have resulted in a significant reduction in tourism demand, especially in international travel, with massive flight cancellations by the world's leading airlines. According to Horta (2020), Portugal is one of the European countries where a strong reduction in tourism activity is expected, with a forecast of more than $40 \%$ in the number of visitors. These values of economic contraction in tourism are only surpassed by Italy and 
Spain. In this sense, this commentary intends to explore the challenges posed by COVID-19 in a country with a strong tourism component like Portugal. Additionally, this perspective also aims to identify opportunities for the development of tourism supply, which necessarily emerge, in the light of the new behavior of tourists motivated by COVID-19.

\section{CHALLENGES POSED BY COVID-19}

COVID-19 has caused a strong impact on international tourism, whose real economic and social effects are still far from being accounted for. We have seen major crashes in commercial aviation, closed hotels, and businesses. These have resulted in heavy losses and large-scale unemployment (ILO, 2020). This panorama is worrying and has an impact on all economies. However, its effect will be potentially greater in countries with a small internal market and where dependence on the outside is higher.

Tourism is extremely important for Portugal as it is indicated in the studies performed by Bento (2016) and Oliveira (2014). News in the media suggests that few are the Portuguese who are not directly or indirectly impacted by this sector of activity, both in the business and family dimensions. With the declaration of the state of emergency on 19th March 2020, motivated by the enlargement of COVID-19, limitations were imposed on the free economic initiative and movement of people. All nonessential services were suspended. In the tourism sector, this has caused the closure of hotels, restaurants, and leisure and recreational activities. Only two exceptions were visible in this area: (i) the continued opening of some hotels and hostels to receive health professionals; (ii) the operation of some takeaway restaurants. This situation caused some important paradigm changes. In the hotels, there has been an increase in the hygienic processes and the establishment of cooperation protocols with health local units. In restaurants, there was an exponential growth in collaboration with home delivery services, which grew strongly in a short period of time.

The challenges faced by companies operating in the tourism sector are complex and can be considered in the short- and long-term perspectives. In the short term, it is important for these companies to have the liquidity to meet expenses, especially with employees and suppliers. Breaking these agreements may lead to chain losses which then become unsustainable. The government has a key role to play here in finding innovative solutions to legislate and support companies financially. One of the best known and most influential measures in this field is the simplified lay-off, in which the 
employee receives two-thirds of his or her gross pay up to a maximum period of three months. According to this model, the employee's renumbering in this period is guaranteed $70 \%$ by Social Security and $30 \%$ by the employer. However, this model may be unfeasible for companies that do not have sufficient liquidity to ensure this support component. Other measures have also emerged that are conceptually interesting, but in practice may prove to be ineffective. Credit lines envisaged by the government may force an excessive debt of enterprises. Moreover, these processes can be excessively bureaucratic and can reach companies too late.

In the long term, the challenges are less concrete but no less demanding. Several uncertainties remain, namely whether after the pandemic the tourist behavior will be similar, whether this activity will decrease or increase, whether a more differentiating tourist offer will be sought. All these issues must be thought through beforehand by tourist operators to anticipate and be highly reactive to market needs. A central point of this challenge is how to deal with a market that may become disruptive.

\section{OPPORTUNITIES FOR DEVELOPMENT}

Portugal has been nominated in recent weeks as a destination of choice for living in the post COVID-19 period (Responsible Tourism, 2020). This recognition is strongly related to the response given by health services in the fight against the pandemic, which makes the country seen abroad with greater confidence than some of the main competitors. Tourists are expected to bring new hygiene and sanitization demands, which causes tourism agents to have to implement clear health safety measures. This is intended to strengthen Portugal's image as a safe destination that has been able to adapt quickly to the new times.

It is expected that tourists' priorities may change and that there will be greater demand for non-mass regions, places where they can have unique experiences and where quality prevails over quantity. Places where there is a demand for social and environmental sustainability, with more nature and fewer crowds, and offered by small hotel units and resorts with a familiar approach, may become the most sought after places by tourists in the post COVID-19 era. This opens a window of opportunity for the emergence of under-exploited tourist sites, in areas like the countryside and the Alentejo. This could also be beneficial in combating the desertification 
of certain regions of the country and reducing the social asymmetries between the coast and the interior of Portugal.

In recent years Portugal has seen an increase in the attraction of the elderly population of Northern and Central Europe, who seek Portugal to live the last years of their lives. According to Lopes et al. (2020), a key reason is weather conditions and the existence of a good private health system that offers good conditions for a person to retire. Considering that this segment of the population is one of the most affected by COVID-19, the incentives to move to a safe and comfortable place in the last years of life are even greater.

Another identified opportunity is the digitalization of tourist operations. The strong role of information technologies and alternative payment methods in the growth of tourism activity and in attracting new audiences is recognized (Almeida et al., 2019). Tour operators should accelerate these digitization processes and promote the establishment of distance businesses and the adoption of new digital platforms (e.g., social networks, virtual congresses, etc.) that allow the formalization of distance businesses and greater diversification of tourism promotion.

\section{CONCLUSION}

Tourism in Portugal has assumed an important role in the economic recovery that Portugal has experienced since the 2011-2014 economic crisis. In this sense, it is expected that the COVID-19 pandemic will have a strong impact on tourism and consequently on the country's economy. Unlike other crises, which allow tourism operators in Portugal to diversify markets and the profile of tourists, this pandemic has caused abrupt and sudden breaks in all activities. Immediately, the COVID-19 caused a severe drop in tourists since the beginning of March and that had an even greater impact with the declaration of the state of emergency. The major dilemma facing businesses is how they will have enough liquidity in the short term to cope with the brutal drop in revenue. In the long term, it is expected that this situation will lead to disruptive movements in the tourism market and that businesses will necessarily need to adapt.

Despite the clear challenges faced by tourism operators, some opportunities can be recognized. Four clusters of opportunities have been identified in this respect: (i) the perception of Portugal as a safe sanitary destination; (ii) the search for places with a less massive tourist offer and that combine the components of social and environmental sustainability; 
(iii) the greater attractiveness of the Portuguese tourist sector to the elderly population; and (iv) the acceleration of the digitalization of tourist operations.

Although the study focuses explicitly on Portugal, the elements identified concerning the challenges and opportunities posed by COVID-19 are relevant for other small-scale economies and countries who looked at tourism as a way to sustain their economic growth. As future work, it would be desirable to perform a comparative study of the challenges posed to small economies, heavily dependent on tourism, and to analyze how the support measures defined in the national and local context have enabled the tourism industry to ensure the sustainability of its operations.

\section{REFERENCES}

Almeida, F., Almeida, J., \& Mota, M. (2019). Perceptions and trends of booking online payments in tourism. Journal of Tourism and Services, 10(18), 1-15.

Bento, J. P. (2016). Tourism and economic growth in Portugal: An empirical investigation of causal links. Tourism \& Management Studies, 12(1), 164-171.

Gössling, S., Scott, D., \& Hall, M. (2021). Pandemics, tourism and global change: a rapid assessment of COVID-19. Journal of Sustainable Tourism, 29(1), 1-20. https://doi.org/10.1080/09669582.2020.1758708

Horta, A. (2020). Tourism in Portugal expected to fall dramatically. Retrieved 7 August, 2020, from https://www.theportugalnews.com/news/tourism-in-portugalexpected-to-fall-dramatically/53926

Ural, M. (2015). Importance of risk management for the sustainability of tourism. Balikesir University the Journal of Social Sciences Institute, 18(33), 163-178.

ILO (2020). COVID-19 and the world of work: Impact and policy responses. Geneve, Switzerland: International Labour Organization.

Lopes M. C., Liberato D., Alén E., \& Liberato, P. (2020). Social tourism development and the population ageing: Case study in Portugal and Spain. In Á. Rocha et al. (eds), Advances in Tourism, Technology and Smart Systems. Smart Innovation, Systems and Technologies (pp. 527-536). Singapore: Springer.

Moreira, C. O. (2018). Portugal as a tourism destination. Méditerranée, 130. https://doi.org/10.4000/mediterranee.10402

Oliveira, E. (2014). The tourism potential of northern Portugal and its relevance for a regional branding strategy. Advances in Hospitality and Tourism Research (AHTR), 2(2), 54-78.

PRESSTUR (2019). Portugal é o $4^{\circ}$ país onde o turismo tem mais 'peso' no emprego total. $\begin{array}{llll}\text { Retrieved } 7 \text { August, 2020, from } & \text {, }\end{array}$ http://www.presstur.com/mercados/portugal/portugal-e-o-4--pais-onde-oturismo-tem-mais-peso-no-emprego-total/

Responsible Tourism (2020). Travel and Tourism after Covid-19. Retrieved 10 August, 2020, from https://responsibletourismpartnership.org/travel-and-tourism-after-covid$19 /$ 
Ritchie, B., \& Jiang, Y. (2019). A review of research on tourism risk, crisis and disaster management: Launching the annals of tourism research curated collection on tourism risk, crisis and disaster management. Annals of Tourism Research, 79, 1-15.

TravelBI (2019). Consumo Turístico representa 14,6\% do PIB em 2018 | Conta Satélite do Turismo 2018. Retrieved 9 August, 2020, from https://ravelbi.turismodeportugal.pt/pt-pt/Paginas/conta-satelite-do-turismo2018.aspx

WEF (2018). The travel E tourism competitiveness report 2018. Geneve, Switzerland: World Economic Forum. 